\title{
ANNOUNCEMENT
}

(c) The Japan Wood Research Society 2018

\section{The 3rd Announcement of the 69th Annual Meeting of the Japan Wood Research Society in Hakodate}

Date: March 14 (Thu)-16 (Sat), 2019

Venue: Hakodate Arena (1-32-1, Yunokawa-cho, Hakodate, Hokkaido, Japan)

Time Table:

\begin{tabular}{|c|c|c|c|c|c|c|}
\hline Date & \multicolumn{2}{|c|}{ March 14 (Thu) } & \multicolumn{2}{|c|}{ March 15 (Fri) } & \multicolumn{2}{|c|}{ March 16 (Sat) } \\
\hline Venue & \multicolumn{2}{|c|}{ Hakodate Arena } & \multicolumn{2}{|c|}{ Hakodate Arena } & \multicolumn{2}{|c|}{ Hakodate Arena } \\
\hline \multirow[t]{2}{*}{ Morning } & $\begin{array}{c}\text { Oral } \\
\text { presentation }\end{array}$ & $\begin{array}{c}\text { Exhibition } \\
\text { of related } \\
\text { companies }\end{array}$ & $\begin{array}{c}\text { Poster } \\
\text { presentation }\end{array}$ & $\begin{array}{c}\text { Exhibition } \\
\text { of related } \\
\text { companies }\end{array}$ & $\begin{array}{c}\text { Oral } \\
\text { presentation }\end{array}$ & $\begin{array}{c}\text { Exhibition } \\
\text { of related } \\
\text { companies }\end{array}$ \\
\hline & & & & & \multicolumn{2}{|c|}{ Closing ceremony } \\
\hline Afternoon & $\begin{array}{c}\text { Oral } \\
\text { presentation }\end{array}$ & $\begin{array}{c}\text { Exhibition } \\
\text { of related } \\
\text { companies }\end{array}$ & $\begin{array}{c}\text { JWRS awards } \\
\text { ceremony } \\
\text { Symposium }\end{array}$ & $\begin{array}{c}\text { Exhibition } \\
\text { of related } \\
\text { companies }\end{array}$ & \multicolumn{2}{|c|}{ Seminars for research groups } \\
\hline Evening & \multicolumn{2}{|c|}{ Wood Science Mixer } & \multicolumn{2}{|c|}{ Banquet } & & \\
\hline
\end{tabular}

Due Dates:

The entry of presentation with an abstract: 17:00 (JST), January 10 (Thu), 2019

Early bird registration: 17:00 (JST), February 15 (Fri), 2019

The Japan Wood Research Society (JWRS) takes great pleasure in inviting all members of our society with an interest in the science and technology of wood to attend the 69th Annual Meeting of the JWRS that will be held from March 14 to 16, 2019, Hakodate, Hokkaido, Japan.

The society members may take oral and poster presentations during the meeting. The symposium and the exhibition of the related companies will also be held.

For more detail information, please visit http://www.jwrs.org/wood2019/index-e.html.

Organizing Committee:

Prof. Dr. Akio Koizumi (Chief)

Prof. Dr. Yuzou Sano (Executive Chief)

Associate Prof. Dr. Yutaka Tamai (Secretary)

Research Faculty of Agriculture, Hokkaido University.

E-mail: wood2019@jwrs.org 